\title{
Overexpression of Phosphoserine Aminotransferase 1 (PSAT1) Predicts Poor Prognosis and Associates with Tumor Progression in Human Esophageal Squamous Cell Carcinoma
}

\author{
Bingyan Liu Yiping Jia Yan Cao Shaoqiu Wu Haosheng Jiang Xianjun Sun \\ Jun Ma Xiang Yin Aiwu Mao Mingyi Shang \\ Department of Interventional Radiology, Tongren Hospital, Shanghai Jiaotong University School of \\ Medicine, Shanghai, PR China
}

\section{Key Words}

Esophageal squamous cell carcinoma (ESCC) - Phosphoserine aminotransferase 1 (PSAT1) • Cell proliferation $\cdot$ Cell invasion $•$ clinicopathological factors

\begin{abstract}
Background/Aims: Phosphoserine aminotransferase 1 (PSAT1) is over-expressed in many carcinoma tissues, however little is known regarding its expression and function in esophageal carcinogenesis. This study investigated the expression of PSAT1 in human esophageal squamous cell carcinoma (ESCC) tissues to determine the relationship between PSAT1 expression and clinicopathological factors. Methods: The expression of PSAT1 in 64 surgical resections from esophageal carcinogenesis patients was examined by quantitative RT-PCR and immunohistochemistry and the results were compared with clinicopathological factors. In vitro experiments were performed in ESCC cells overexpressing PSAT1 to measure cell viability and invasion. Tumor formation in vivowas examined by injection of tumor cells into immunocompromised mice subcutaneously. Results: PSAT1 expression was elevated in ESCC tissues compared to normal esophageal tissues. Increased PSAT1 expression was significantly associated with stage of disease, lymph node metastasis, distant metastasis and poor prognosis. In vitro, PSAT1 overexpression promoted ESCC cell proliferation and matrigel invasion. In vivo, injection of mice with ECSS cells overexpressing PSAT1 enhanced tumor formation. Western blot analysis revealed that PSAT1 upregulated the expression and/or activity of GSK3ß/Snail. Conclusion: PSAT1 plays a crucial role in the development of ESCC and predicts poor survival. Therefore, PSAT1 may be a promising novel anticancer therapeutic target.
\end{abstract}

Copyright (C) 2016 S. Karger AG, Basel

B. Liu and Y. Jia contributed equally to this work and should be regarded as joint first authors. 


\begin{tabular}{cl|l} 
Cellular Physiology & \multicolumn{2}{c}{ Cell Physiol Biochem 2016;39:395-406 } \\
and Biochemistry & $\begin{array}{l}\text { Dol: 10.1159/000445633 } \\
\text { Published online: July 04, 2016 }\end{array}$ & $\begin{array}{l}\text { O 2016 S. Karger AG, Basel } \\
\text { www.karger.com/cpb }\end{array}$ \\
\cline { 2 - 3 } & Liu et al:: Role of PSAT1 in ESCC &
\end{tabular}

\section{Introduction}

Esophageal cancer is a particularly aggressive malignancy with a high mortality rate. It is the eighth most common cancer globally and the sixth most common cause of cancerrelated death [1-4]. This type of cancer is about four times more common in men than in women and there are vastly different rates of occurrence between countries with China accounting for about half of all cases [5, 6]. There are two main causes of esophageal cancer, esophageal squamous cell carcinoma (ESCC) and esophageal adenocarcinoma (EAC). ESCC derives from epithelial cells that line the esophagus, whereas EAC arises from glandular cells in the lower third of the esophagus. ESCC is the predominant cause of esophageal cancer being responsible for approximately $60-70 \%$ of all cases of esophageal cancer worldwide, while EAC accounts for 20-30\%, and a number of less common types also occur. However, the incidence of EAC is steadily increasing [7, 8]. Any factor which causes chronic irritation and inflammation increases the risk of ESCC, and tobacco and alcohol consumption are therefore well established as the primary risk factors for $\operatorname{ESCC}[9,10]$. In contrast, obesity is frequently linked with EAC and the increased prevalence of obesity parallels the increased incidence of EAC $[11,12]$. Treatment is based on the stage and location of the cancer and clinical outcomes depend on the extent of the disease but generally tend to be poor as diagnosis is often late with this type of cancer.

Serine and glycine metabolism plays a vital role in cell proliferation as these amino acids are essential precursors for macromolecule synthesis and are important in maintaining the cellular redox state. In recent years, hyperactivation of the serine/glycine metabolic pathway has been implicated in cancer pathogenesis [13]. It has been suggested that the selective expression of some metabolic enzymes operates as a prognostic factor for cancer [14]. Serine is synthesized via a three-step reaction: (1) the conversion of 3-phosphoglycerate to 3-phosphohydroxypuruvate, catalyzed by phosphoglycerate dehydrogenase (PHGDH), (2) the conversion of 3-phosphohydroxypuruvate to phosphoserine by the enzyme phosphoserine phosphatase (PSPH), and (3) the conversion of phosphoserine to serine by phosphoserine aminotransferase (PSAT1). The enzyme that catalyzes the first step in the serine biosynthetic pathway, PHGDH, has been shown to have prognostic value in predicating patient survival in regard to breast cancer but not lung cancer, indicating that other mechanisms may be employed in other cancer types, potentially other serine metabolic enzymes [14]. PSAT1 has been shown to promote cell proliferation and chemoresistance in vitro $[15,16]$ and this enzyme has been closely associated with tumorigenesis in colon cancer, breast cancer and non-small cell lung cancer by regulating cell-cycle [17-20]. There is evidence that PSAT1 could function as a pro-proliferative and pro-survival factor during carcinogenesis. Even less is known about the expression and underlying mechanism by which PSAT1 contributes to ESCC development and progression.

Our previous studies found that PSAT1 as a direct target of miR-340, may contribute to the progression and invasiveness of ESCC [21]. In this study, we analyze the role of PSAT1 in the development of ESCC and investigate the relationship between PSAT1 expression and clinicopathological factors including patient prognosis. Taken together, our data identify PSAT1 as a potential novel therapeutic target in esophageal cancer.

\section{Materials and Methods}

Patients and tissue specimens

Patients selected for this study were diagnosed with ESCC from 2004 to 2007 at the Tongren Hospital, and underwent esophageal cancer resection, prior to the administration of chemotherapy. ESCC and carcinoma-adjacent tissues were collected immediately after surgical resection, and confirmed by experienced pathologists. All samples were deposited in the Tissue Bank of Tongren Hospital, Shanghai Jiaotong University School of Medicine and coded anonymously in accordance with local ethical guidelines (as stipulated by the Declaration of Helsinki). Written informed consent was obtained from all patients, 


\begin{tabular}{|c|c|c|}
\hline Cellular Physiology & Cell Physiol Biochem 2016;39:395-406 & \\
\hline and Biochemistry & $\begin{array}{l}\text { DOI: 10.1159/000445633 } \\
\text { Published online: July 04, } 2016\end{array}$ & $\begin{array}{l}\text { O } 2016 \mathrm{~S} \text {. Karger AG, Basel } \\
\text { www.karger.com/cpb }\end{array}$ \\
\hline
\end{tabular}

and the protocol was approved by the Review Board of Shanghai Jiaotong University School of Medicine (approval number: 20120614-XF). ESCC specimens were staged in accordance with the American Joint Cancer Committee/Union Internationale Contre le Cancer (UICC/AJCC) classification guidelines. The grading and histopathological subtyping of ESCC specimens was based on the World Health Organization criteria. Sixty-four ESCC biopsy samples and their adjacent matching noncancerous esophageal tissues were dissected manually to remove connective tissues and were then immediately stored in liquid nitrogen until further use. Summary of clinical and histopathological characteristics of this sample cohort are in Table 1.

Table 1. Demographic, clinical, histopathological, and characteristics of patients

\begin{tabular}{|c|c|c|c|c|c|c|c|}
\hline Patient & Age/Sex & $\begin{array}{c}\text { Tomor } \\
\text { location }\end{array}$ & $\begin{array}{l}\text { TNM } \\
\text { stage }\end{array}$ & $\begin{array}{l}\text { Primary tumour } \\
\text { (T) stage }\end{array}$ & $\begin{array}{l}\text { Lymph node } \\
\text { metastasis }\end{array}$ & $\begin{array}{c}\text { Distant } \\
\text { metastasis }\end{array}$ & $\begin{array}{c}\text { PSAT1 } \\
\text { Expression } \\
\text { (SI) }\end{array}$ \\
\hline 1 & $56 / F$ & Middle & II & T2 & No & No & 3 \\
\hline 2 & $60 / \mathrm{M}$ & Middle & IV & $\mathrm{T} 4$ & Yes & No & 4 \\
\hline 3 & $48 / \mathrm{M}$ & Upper & I & T1 & No & No & 0 \\
\hline 4 & $59 / \mathrm{F}$ & Middle & IV & $\mathrm{T} 4$ & Yes & No & 3 \\
\hline 5 & $42 / \mathrm{M}$ & Middle & I & T1 & No & No & 2 \\
\hline 6 & $54 / \mathrm{M}$ & Middle & III & T3 & Yes & No & 0 \\
\hline 7 & $61 / \mathrm{F}$ & Middle & IV & $\mathrm{T} 3$ & Yes & Yes & 4 \\
\hline 8 & $50 / \mathrm{M}$ & Upper & II & $\mathrm{T} 2$ & No & No & 0 \\
\hline 9 & $45 / \mathrm{F}$ & Middle & IV & $\mathrm{T} 4$ & Yes & No & 1 \\
\hline 10 & $63 / F$ & Lower & IV & T3 & Yes & Yes & 3 \\
\hline 11 & $56 / \mathrm{M}$ & Middle & III & $\mathrm{T} 1$ & Yes & No & 4 \\
\hline 12 & $52 / \mathrm{M}$ & Middle & II & $\mathrm{T} 2$ & No & No & 0 \\
\hline 13 & $59 / \mathrm{M}$ & Middle & III & $\mathrm{T} 3$ & Yes & No & 1 \\
\hline 14 & $54 / \mathrm{M}$ & Middle & IV & T4 & Yes & No & 4 \\
\hline 15 & $50 / \mathrm{M}$ & Upper & III & $\mathrm{T} 3$ & No & No & 3 \\
\hline 16 & $61 / \mathrm{M}$ & Lower & III & T3 & No & No & 0 \\
\hline 17 & $65 / F$ & Middle & III & $\mathrm{T} 2$ & Yes & No & 3 \\
\hline 18 & $43 / \mathrm{M}$ & Middle & IV & $\mathrm{T} 4$ & No & No & 1 \\
\hline 19 & $51 / \mathrm{M}$ & Upper & I & $\mathrm{T} 1$ & No & No & 0 \\
\hline 20 & $57 / \mathrm{M}$ & Middle & III & $\mathrm{T} 2$ & Yes & No & 4 \\
\hline 21 & $50 / \mathrm{M}$ & Middle & III & $\mathrm{T} 3$ & Yes & No & 3 \\
\hline 22 & $56 / \mathrm{M}$ & Middle & III & T3 & Yes & No & 1 \\
\hline 23 & $64 / F$ & Lower & II & $\mathrm{T} 2$ & No & No & 0 \\
\hline 24 & $49 / \mathrm{M}$ & Middle & II & $\mathrm{T} 2$ & No & No & 1 \\
\hline 25 & $55 / \mathrm{M}$ & Middle & III & T3 & Yes & No & 0 \\
\hline 26 & $58 / \mathrm{M}$ & Lower & IV & $\mathrm{T} 3$ & No & Yes & 2 \\
\hline 27 & $47 / F$ & Middle & I & $\mathrm{T} 1$ & No & No & 4 \\
\hline 28 & $52 / \mathrm{M}$ & Middle & III & T3 & Yes & No & 1 \\
\hline 29 & $56 / F$ & Middle & III & $\mathrm{T} 3$ & Yes & No & 4 \\
\hline 30 & $51 / \mathrm{M}$ & Middle & II & $\mathrm{T} 2$ & No & No & 0 \\
\hline 31 & $53 / \mathrm{M}$ & Middle & IV & $\mathrm{T} 4$ & No & No & 4 \\
\hline 32 & $57 / \mathrm{M}$ & Middle & III & $\mathrm{T} 1$ & Yes & No & 0 \\
\hline 33 & $60 / \mathrm{M}$ & Middle & IV & T3 & Yes & Yes & 1 \\
\hline 34 & $55 / \mathrm{M}$ & Middle & III & T3 & No & No & 2 \\
\hline 35 & $52 / \mathrm{M}$ & Middle & IV & $\mathrm{T} 4$ & Yes & Yes & 4 \\
\hline 36 & $44 / \mathrm{F}$ & Upper & II & $\mathrm{T} 2$ & No & No & 1 \\
\hline 37 & $54 / \mathrm{M}$ & Upper & III & $\mathrm{T} 3$ & Yes & No & 4 \\
\hline 38 & $58 / \mathrm{M}$ & Middle & IV & $\mathrm{T} 4$ & No & No & 1 \\
\hline 39 & $50 / \mathrm{M}$ & Middle & I & $\mathrm{T} 1$ & No & No & 2 \\
\hline 40 & $49 / \mathrm{M}$ & Middle & III & $\mathrm{T} 2$ & Yes & No & 3 \\
\hline 41 & $58 / \mathrm{F}$ & Middle & IV & $\mathrm{T} 4$ & Yes & Yes & 4 \\
\hline 42 & $55 / \mathrm{M}$ & Middle & II & $\mathrm{T} 2$ & No & No & 1 \\
\hline 43 & $51 / \mathrm{M}$ & Lower & IV & $\mathrm{T} 2$ & Yes & Yes & 3 \\
\hline 44 & $47 / \mathrm{M}$ & Middle & III & $\mathrm{T} 1$ & Yes & No & 2 \\
\hline 45 & $50 / \mathrm{M}$ & Middle & III & T3 & Yes & No & 4 \\
\hline 46 & $55 / F$ & Lower & I & $\mathrm{T} 1$ & No & No & 0 \\
\hline 47 & $53 / \mathrm{M}$ & Middle & II & $\mathrm{T} 2$ & No & No & 4 \\
\hline 48 & $56 / \mathrm{M}$ & Middle & IV & $\mathrm{T} 4$ & Yes & Yes & 4 \\
\hline 49 & $49 / \mathrm{F}$ & Middle & III & T3 & Yes & No & 3 \\
\hline 50 & $54 / \mathrm{M}$ & Middle & IV & $\mathrm{T} 4$ & Yes & No & 3 \\
\hline 51 & $51 / \mathrm{M}$ & Middle & II & $\mathrm{T} 2$ & No & No & 0 \\
\hline 52 & $59 / \mathrm{M}$ & Middle & II & $\mathrm{T} 2$ & No & No & 1 \\
\hline 53 & $62 / \mathrm{M}$ & Middle & IV & $\mathrm{T} 3$ & Yes & Yes & 4 \\
\hline 54 & $45 / \mathrm{M}$ & Middle & III & T3 & Yes & No & 4 \\
\hline 55 & $66 / \mathrm{M}$ & Lower & IV & $\mathrm{T} 4$ & No & No & 0 \\
\hline 56 & $59 / \mathrm{F}$ & Middle & III & T3 & No & No & 0 \\
\hline 57 & $56 / \mathrm{M}$ & Middle & I & $\mathrm{T} 1$ & No & No & 3 \\
\hline 58 & $48 / \mathrm{M}$ & Middle & I & $\mathrm{T} 1$ & No & No & 0 \\
\hline 59 & $55 / \mathrm{M}$ & Upper & IV & $\mathrm{T} 4$ & No & Yes & 4 \\
\hline 60 & $57 / \mathrm{M}$ & Middle & III & T2 & Yes & No & 4 \\
\hline 61 & $59 / \mathrm{M}$ & Middle & III & $\mathrm{T} 1$ & Yes & No & 4 \\
\hline 62 & $41 / \mathrm{F}$ & Middle & IV & T3 & Yes & Yes & 3 \\
\hline 63 & $60 / \mathrm{M}$ & Lower & II & $\mathrm{T} 2$ & No & No & 2 \\
\hline 64 & $53 / \mathrm{F}$ & Middle & IV & $\mathrm{T} 4$ & Yes & No & 4 \\
\hline
\end{tabular}




\begin{tabular}{|c|c|c|}
\hline Cellular Physiology & Cell Physiol Biochem 2016;39:395-406 & \\
\hline and Biochemistry & $\begin{array}{l}\text { DOI: 10.1159/000445633 } \\
\text { Published online: July 04, } 2016\end{array}$ & $\begin{array}{l}\text { O } 2016 \mathrm{~S} \text {. Karger AG, Basel } \\
\text { www.karger.com/cpb }\end{array}$ \\
\hline
\end{tabular}

Cell lines and culture conditions

An immortalized human esophageal squamous epithelial cell line (HET-1A) was purchased from American type culture collection and was grown in RPMI-1640 (Gibco, Carlsbad, CA, USA) medium supplemented with $10 \%$ fetal bovine serum (FBS, Gibco). Human embryonic kidney HEK293T cells and three ESCC cell lines (EC1, EC109, EC9706) were purchased from the Chinese Academy of Medical Science (Shanghai, China) and were routinely maintained in Dulbecco's modified Eagle's medium (DMEM) or RPMI1640 medium (Gibco) supplemented with $10 \%$ fetal bovine serum, 100 units/ml penicillin G and $100 \mu \mathrm{g} /$ $\mathrm{ml}$ streptomyc in at $37^{\circ} \mathrm{C}$ in humidified air containing $5 \% \mathrm{CO}_{2}$.

\section{Quantitative real-time PCR}

Total cellular RNA was isolated from cells using Trizol (Invitrogen, Carlsbad, CA, USA) according to the manufacturer's protocol. RNA was eluted with RNase-free water, quantified at an absorbance at 260/280 $\mathrm{nm}$, and used for reverse transcription. cDNA was synthesized by oligo (dT) priming using the RevertAidTM First Strand cDNA Synthesis Kit (Fermentas, Burlington, ON, Canada) according to the manufacturer's instructions. Real-time quantitative PCR was performed using a commercial SYBR-Green master mix kit (Takara, Tokyo, Japan) and a Prism 7900 Sequence Detection System (Applied Biosystems, Foster City, CA, USA). GAPDH was included as an internal control. Each sample was measured in triplicate. Primers and probes for real-time quantitative PCR were purchased from Applied Biosystems. The primer sequences for PSAT1 were F: 5'-GGCCAGTTCAGTGCTGTCC-3' and R: 5'-GCTCCTGTCACCACATAGTCA-3', and for GAPDH were F: 5'-CTGGGCTACACTGAGCACC-3' and R: 5'-AAGTGGTCGTTGAGGGCAATG-3'.

\section{Plasmid constructs and lentiviral transduction}

To generate the lentiviral vector pCDH-PSAT1 that overexpresses PSAT1, the full coding sequence was amplified by PCR from HEK293T cell cDNA and then cloned into the BamHI/EcoRI sites of the pCDHCMV-EF1-copGFP vector (SBI, Mountain View, CA, USA) using the following primers: forward primer, 5'-AAAGAATTCATGGACGCCCCCAGGCAG-3'; reverse primer: 5'-AAAGGATCCTCATAGCTGATGCATCTCCAAAA AT-3'. The correct insertions were confirmed by DNA sequencing.

For the production of viral particles, the lentivirus-mediated PSAT1packaging system containing pCDH-CMV-EF1-copGFP or pCDH-PSAT1was co-transfected with Rec, TAT, Gag and Vsvg into HEK293T cells with Lipofectamine ${ }^{\mathrm{TM}} 2000$ (Invitrogen) according to the manufacturer's instructions. The supernatant containing the virus source was collected $60 \mathrm{~h}$ post-transfection and passed through a $0.45-\mu \mathrm{m}$ pore size filter (Millipore, Bedford, MA, USA).

Cells were grown in log phase and then transfected with either pCDH-CMV-EF1-copGFP (vector) or pCDH-PSAT 1 for $24 \mathrm{~h}$. Stable cell lines were screened by mass sorting on a FACSAria flow cytometer (BD Biosciences, San Jose, CA, USA) based on the expression of GFP carried by the lentiviral vector $72 \mathrm{~h}$ after transfection.

\section{Small interfering RNA and gene transfection}

ESCC cells $\left(5 \times 10^{6}\right)$ in $2 \mathrm{ml}$ of culture medium were transfected with 100 pmol of control siRNA (NC) or targetPSAT1 mixed withlip ofectamine2000 reagentinserum reducedmediumaccordingtothemanufacturer's instructions. The siRNA sequences were as follows: Control siRNA: AACGUACGCGGAAUACUUCdTdT, PSAT1 siRNA \#1: GUCAGCACACCUUCCUGCUdTdT, PSAT1 siRNA \#2: CAGGCAAGUUUGAAAUCUdTdT, PSAT1 SiRNA \#3: UUCCAGUUCAAGUCAGAAdTdT. The medium was changed to complete culture medium $6 \mathrm{~h}$ later, and the cells were incubated at $37^{\circ} \mathrm{C}$ in a $\mathrm{CO}_{2}$ incubator for another $48 \mathrm{~h}$ before harvesting.

\section{Cell invasion assays}

For the cell invasion assay, the filter membrane with a pore size of $8 \mu \mathrm{m}$ (Corning, Acton, MA, USA) was coated with Matrigel (BD Biosciences) diluted 1:5in serum-free RPMI 1640 medium. After air-drying and sterilization, $29 \mu \mathrm{l}$ of RPMI 1640 medium with serum added was placed in the lower chamber of the Costar transwell (Corning). Then, the above transfected cells were trypsinized and resuspended in serumfree RPMI 1640 with a density of $1.2 \times 10^{6} / \mathrm{ml}$ and seeded $50 \mu \mathrm{l}$ in the upper chamber, then incubated at $37^{\circ} \mathrm{C}$ for $20 \mathrm{~h}$. Non-invading cells remaining on the upper surface of the filter were removed with a cotton swab and rinsed with PBS several times, and the cells that appeared on the lower surface of the filter were fixed with methanol for more than $15 \mathrm{~min}$ at $-20^{\circ} \mathrm{C}$ and then washed in PBS, stained with crystal purple and counted under a microscope. 


\begin{tabular}{|c|c|c|}
\hline Cellular Physiology & Cell Physiol Biochem 2016;39:395-406 & \\
\hline and Biochemistry & $\begin{array}{l}\text { DOI: 10.1159/000445633 } \\
\text { Published online: July 04, } 2016\end{array}$ & $\begin{array}{l}\text { O } 2016 \mathrm{~S} \text {. Karger AG, Basel } \\
\text { www.karger.com/cpb }\end{array}$ \\
\hline
\end{tabular}

Cell proliferation assay

To determine the effect of PSAT1 on cell proliferation, cells with and without PSAT1 were seeded into 96-well plate at a density of $4 \times 10^{3} /$ well/200 $\mu \mathrm{l}$ in the maintenance medium. Viable cells were quantified 24, 48, 72 and $96 \mathrm{~h}$ after seeding by the chromogenic 3-[4,5-dimethylthiazol-2-yl]-2,5-diphenyltetrazoliumbromide (MTT) assay according to the manufacturer's instruction (Sigma, St. Louis, MO, USA). Each assay was performed in triplicate.

Immunohistochemistry analysis

Immunohistochemistry staining was performed with the polyclonal primary antibody against PSAT1 at 1:50 dilution (Proteintech Group Inc, Chicago, IL, USA). Negative controls were conducted by replacing the primary antibody with phosphate-buffered saline. After washing, the sections were incubated with a biotinylated anti-rabbit secondary antobody at 1:200 dilution (Abcam, Cambridge, MA, USA) and then with a streptavidin-horseradish peroxidase complex (Abcam) causing yellow particles. Finally, the tissue sections were immersed in 3.30-diaminobenzidine (DAB), counterstained with hematoxylin, dehydrated and mounted in crystal mount medium. PSAT1 expression was evaluated by two independent pathologists (W.C. and B.S.). In this study, the PSAT1staining index (SI) was ranked only according to the percentage of positive cells marked by yellow particles observed in tumor cytoplasm/cell plasma membrane. Samples in which $0 \%$ of cells showed negative staining were rated 0 , those with $<25 \%$ of cells showed positive staining were rated 1 , those with $25 \%$ to $50 \%$ positive stained were rated 2 , those with $51 \%$ to $75 \%$ positive stained were rated 3 , those with $>75 \%$ positive stained were rated 4 . We defined that SI $>1$ indicated tumours with high PSAT1 expression and SI 1 indicated low/negative PSAT1expression.

Tumorigenicity in $B A L B / c$ Scid mice

The animal experimentation was performed according to the Institutional Animal Care and Use Committee guidelines of the Experiment Animal center of Shanghai Jiaotong University School of Medicine, and the approval ID as No 140624-F by Experiment Animal Center of Shanghai Jiaotong University School of Medicine. BALB/C-nu/nu nude mice were obtained from Shanghai Laboratory Animal Center of China and were housed in specific pathogen-free conditions. Approximately $1 \times 10^{7}$ cells of each cell line in $200 \mu \mathrm{l}$ of medium without serum were injected subcutaneously into the upper back of nude mice. Tumor growth was measured with calipers every seven days and the tumor volumes were calculated using the formula: $1 / 2$ (length $\times$ width $^{2}$ ). Mice were euthanized and tumor weight was examined five weeks later.

Western blot analysis

Cultured cells were harvested and lysed in lysis buffer (Cell Signaling Technology, Beverly, MA, USA). Proteins were separated by $10 \%$ SDS-PAGE and then transferred onto PVDF membranes (Millipore, Boston, MA, USA). Membranes were blocked with $5 \%$ skim milk and then incubated overnight at $4{ }^{\circ} \mathrm{C}$ with primary antibodies in TBS-T (10 mM Tris-HCl pH 8, $150 \mathrm{mMNaCl}, 0.1 \%$ Tween 20). The following antibodies were

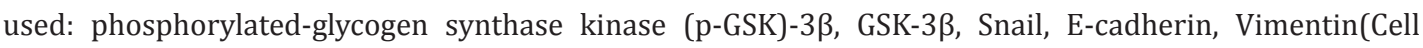
Signaling Technology) and GAPDH antibody (Santa Cruz Biotechnology, Santa Cruz, CA, USA) as an internal control. After washing, membranes were incubated with peroxidase-conjugated secondary antibodies for 2 h. Signals were detected using a chemiluminescence detection kit (Pierce Biotechnology Inc., Rockford, IL, USA) according to the manufacturer's protocols.

\section{Statistical analysis}

All data were presented as mean \pm SD. The correlation was analyzed by t-test or ANOVA method. Statistical analyses were performed with SPSS 16.0 software(SPSS, Chicago, IL, USA).P $<0.05$ was considered statistically significantly different. For western blot, the relative protein levels were quantified by the ratio to loading control GAPDH. The means \pm S.D. of three blots were shown.

\section{Results and Discussion}

Expression patterns of PSAT1 in ESCC cell lines and ESCC tissues

The relative mRNA expression levels of PSAT1 were analyzed in 64 ESCC biopsy samples (tumor tissue) and their adjacent matching noncancerous esophageal tissues (non-tumor 
A

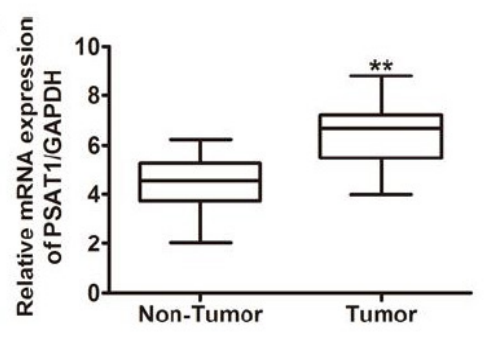

$\mathrm{C}$

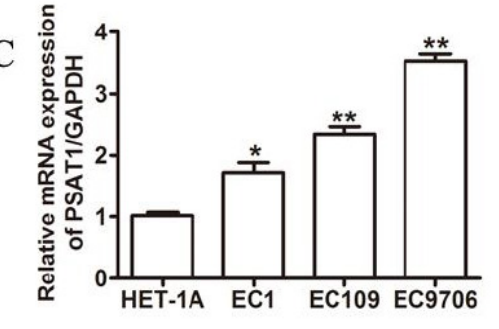

$\mathrm{D}$

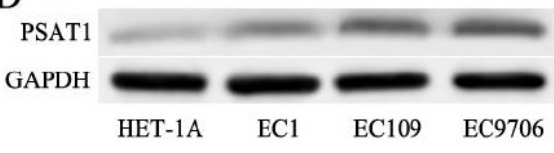

B
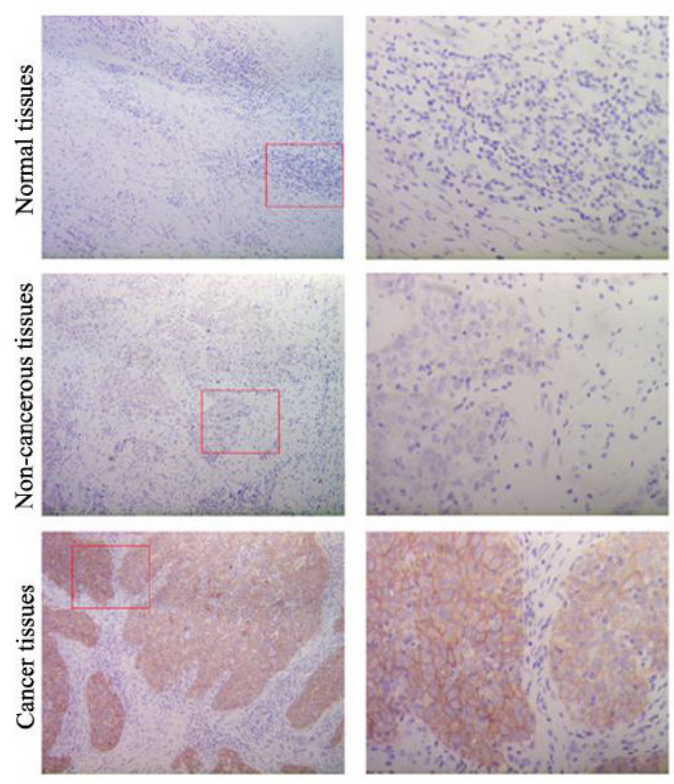

Fig. 1. Upregulation of PSAT1 in ESCC cell lines and tissues. (A) qRT-PCR to compare PSAT1 mRNA levels between tumor and corresponding non-tumor tissues from 64 ESCC cases. ${ }^{* *}, \mathrm{P}<0.01$. (B) Representative immunhistochemical staining for PSAT1 in ESCC samples,adjacent non-canceroustissues and normal esophageal tissues. Positive staining (brown) was detected in tumor cells but not in adjacent non-tumor and normal esophageal tissues. Original magnification ( $\times 100$, full, left; $\times 400$, partial enlargement, right). (C) The mRNA expression of PSAT1 was evaluated in three ESCC cell lines by qRT-PCR, HEEC were included as a control. (D) The protein level of PSAT1 was detected by western blot analysis in the same cell lines. GAPDH was used as a loading control.

tissue) taken from patients diagnosed with ESCC by qRT-PCR. PSAT1 mRNA expression levels significantly increased $(\mathrm{P}<0.01)$ in ESCC tumor tissues compared with the corresponding non-tumor tissues (Fig. 1A). On immunostaining with PSAT1 antibody, positive staining (brown) was detected in tumor tissue but not in non-tumor tissue and normal esophageal tissues, indicating that PSAT1 is specifically expressed in cancerous tissue. Representative images are shown in Fig. 1B.

Next, the relative mRNA expression levels of PSAT1 were analyzed in three ESCC cell lines (EC1, EC109, EC9706) and a HEEC cell line by qRT-PCR (Fig. 1C). PSAT1 expression was significantly increased ( $<<0.01$ for EC109 and EC9706; P $<0.05$ for EC1) in the ESCC cell lines compared with the esophageal epithelialcell line (HECC). Western blot analysis of the PSAT1 protein levels revealed the same trend, with increased expression in the ESCC cell lines compared with the HEEC cell line (Fig. 1D). This indicated that mRNA and protein expression of PSAT1 is elevated in ESCC cells compared with normal esophageal cells.

The clinical significance of PSAT1 expression in ESCC

The potential relationship between elevated expression of PSAT1 and various clinicopathological parameters was investigated. As shown in Table 2, elevated expression of PSAT1 was significantly associated with tumor stage $(\mathrm{P}=0.0211)$, lymph node metastasis $(\mathrm{P}=0.0011)$ and distant metastasis $(\mathrm{P}=0.0193)$, and there was no significant association with gender, age or tumor location.

\section{KARGER}




\begin{tabular}{|c|c|c|}
\hline Cellular Physiology & Cell Physiol Biochem 2016;39:395-406 & \\
\hline and Biochemistry & $\begin{array}{l}\text { DOI: 10.1159/000445633 } \\
\text { Published online: July 04, } 2016\end{array}$ & $\begin{array}{l}\text { Q 2016 S. Karger AG, Basel } \\
\text { www.karger.com/cpb }\end{array}$ \\
\hline
\end{tabular}

Furthermore, a log-rank test and KaplanMeier analysis were used to calculate the effect of PSAT1 on survival. In order to classify all ESCC patients into high PSAT1 expression and low PSAT1 expression groups, negative and low PSAT1expressionwas determined as low expression group and moderate and high PSAT1expression was determined as high expression group. The log-rank test showed that the expression level of PSAT1 protein attested remarkably to patients' survival time (Fig. 2).The overall survival rates in ESCC patients with low $(\mathrm{n}=26)$ and high PSAT1 protein $(n=38)$ were $23.14 \%$ and $43.35 \%$, respectively, which represents a statistically significant difference $(\mathrm{P}=0.0107)$. More specifically, the median survival time of patients with high expression levels of PSAT1 protein was only 41 months, whereas the median survival time of those with low levels of PSAT1 protein was 55 months. These findings revealed a significant association between increased PSAT1 expression and poor clinical prognosis.

\section{PSAT1 promotes growth of ESCC cell lines} in vitro and in vivo

To further investigate the role of PSAT1 in ESCC cell lines, PSAT1 expression was increased in EC1 cells by transfection with the lentiviral vector pCDH-PSAT1 that overexpresses PSAT1.PSAT1 protein expression in the EC1 stable transfectants was detected by western blot analysis and high levels of PSAT1 expression were detected compared with the no vector and vector only controls (Fig. 3A). Viability of the EC1 stable transfectants was measured by the MTT assay (Fig. 3B) and cell viability was found to be significantly higher $(\mathrm{P}<0.01)$ in the EC1-PSAT1 cells compared with the EC1Vector cells, indicating the growth advantage conferred by PSAT1.

In vivo tumor formation was examined by subcutaneously injecting EC1-Vector or EC1-PSAT1 transfected cells into athymic nude mice. Tumor volume was then measured at weekly intervals. As shown in Fig. 3C, after five weeks tumors were significantly larger in mice injected with EC1PSAT1 cells compared with those injected with EC1-Vector cells (Student's t-test, $P$ $=0.021$ ), suggesting that PSAT1 enhances tumor formation in vivo.
Table 2. Relationship between PSAT1 expression and clinicopathological parameters in ESCC patients. $\chi 2$ test was employed. ${ }^{*}$ Statistically significant

\begin{tabular}{|c|c|c|c|}
\hline \multirow[t]{2}{*}{ Parameter } & \multicolumn{2}{|c|}{ PSAT1 protein expression } & \multirow[t]{2}{*}{$P$ value } \\
\hline & $\begin{array}{l}\text { Negative/ } \\
\text { Low }(n=26)\end{array}$ & $\begin{array}{l}\text { High } \\
(\mathrm{n}=38)\end{array}$ & \\
\hline \multicolumn{4}{|l|}{ Age } \\
\hline$<54$ & 12 & 16 & 0.748 \\
\hline$\geq 54$ & 14 & 22 & \\
\hline \multicolumn{4}{|l|}{ Gender } \\
\hline Male & 21 & 27 & 0.378 \\
\hline Female & 5 & 11 & \\
\hline \multicolumn{4}{|l|}{ TNM stage } \\
\hline I & 4 & 4 & $0.030^{*}$ \\
\hline II & 9 & 3 & \\
\hline III & 8 & 15 & \\
\hline IV & 5 & 16 & \\
\hline \multicolumn{4}{|c|}{ Tumor location } \\
\hline Upper & 4 & 3 & 0.499 \\
\hline Middle & 18 & 31 & \\
\hline Lower & 4 & 4 & \\
\hline \multicolumn{4}{|c|}{ Primary tumour (T) stage } \\
\hline $\mathrm{T} 1$ & 5 & 7 & 0.578 \\
\hline $\mathrm{T} 2$ & 9 & 8 & \\
\hline T3 & 8 & 13 & \\
\hline $\mathrm{T} 4$ & 4 & 10 & \\
\hline \multicolumn{4}{|c|}{ Lymph node metastasis } \\
\hline No & 19 & 12 & $0.001^{*}$ \\
\hline Yes & 7 & 26 & \\
\hline \multicolumn{4}{|c|}{ Distant metastasis } \\
\hline No & 25 & 28 & $0.019^{*}$ \\
\hline Yes & 1 & 10 & \\
\hline
\end{tabular}

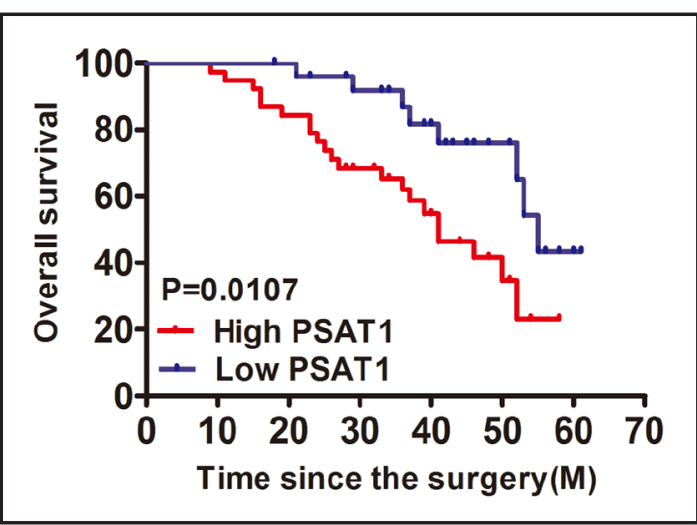

Fig. 2. Kaplan-Meier survival curves of ESCC patients. The overall survival rates in ESCC patients with low $(\mathrm{n}=26)$ and high $(\mathrm{n}=38)$ PSAT1 protein levels were $23.14 \%$ and $43.35 \%$, respectively, showing a statistically significant difference $(P=0.0107)$. 


\begin{tabular}{|c|c|c|}
\hline Cellular Physiology & Cell Physiol Biochem 2016;39:395-406 & \\
\hline and Biochemistr & $\begin{array}{l}\text { DOI: 10.1159/000445633 } \\
\text { Published online: July 04, } 2016\end{array}$ & $\begin{array}{l}\text { O } 2016 \text { S. Karger AG, Basel } \\
\text { www.karger.com/cpb }\end{array}$ \\
\hline
\end{tabular}

Fig. 3. The effect of PSAT1 on cell growth in vitro and in vivo. (A) PSAT1 protein expression in the EC1 stable transfectants was detected by western blot analysis. GAPDH was used as a loading control. The image is representative of three independent experiments. (B) Viability of the EC1 stable transfectantsas measured by an MTT assay. Results show the mean \pm standard deviation of three independent experiments. (C) Mice were injected with EC1-Vector or EC1-PSAT1 cells and nursed for 35 days. Tumor size was then measured at weekly intervals. Results show the mean \pm standard deviation of three mice (Student's t-test, $\mathrm{P}=$ 0.021). (D) PSAT1 protein expression in the
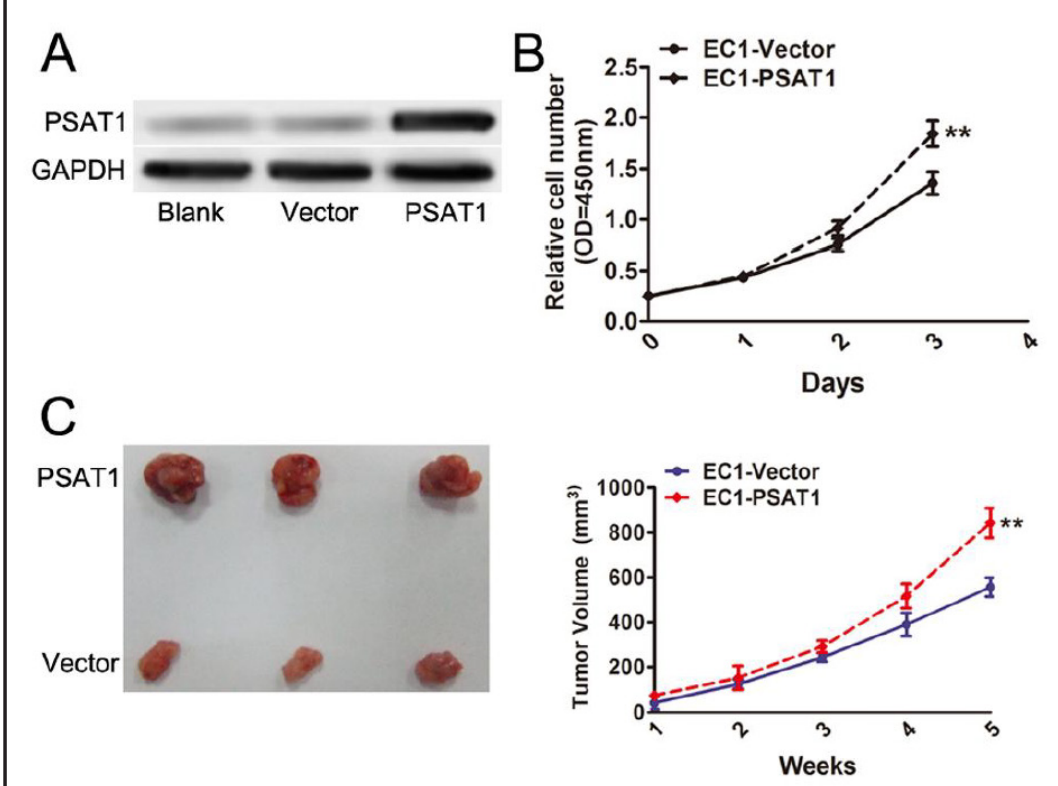

EC9706 cells transfected with PSAT1 siRNA (\#1,\#2,\#3) was detected by western blot analysis. GAPDH was used as a loading control. (E) Viability of the EC9706 cells transfected with PSAT1 siRNA as measured by an MTT assay. ${ }^{*}, \mathrm{p}<0.05 ;{ }^{* *}, \mathrm{p}<0.01$.

To further analyze the function of the PSAT1 gene in ESCC cells, knockdown of PSAT1 was achieved by transfecting EC9706 cells with PSAT1-targeted RNAi (PSAT1 siRNA) or a negative control.PSAT1 protein expression in the EC9706 cells transfected with PSAT1 siRNA was detected by western blot analysis and expression was dramatically reduced in all three PSAT1 siRNA-transfected cells (siRNA \#1, siRNA \#2, siRNA \#3)compared with the negative control (Fig. 3D), indicating effective knockdown of PSAT1.PSAT1 siRNA \#1 was selected as being representative and was used in subsequent experiments. The viability of EC9706 cells transfected with PSAT1 siRNA was measured by the MTT assay and EC9706-siPSAT1 cells showed significantly reduced cell viability compared with EC9706-NC (negative control) cells $(\mathrm{P}<0.01 ;$ Fig. 3E). This confirmed the role of PSAT1 in cell proliferation.

\section{PSAT1 induces cell invasion in ESCC cell lines}

To investigate the effect of PSAT1 on cell invasion, an in vitro Matrigel assay was performed, firstly in EC1 cells transfected with PSAT1-expressing or control vector and secondly in EC9706 cells transfected with PSAT1 siRNA or negative control, representative images are presented in Fig. 4A and B respectively. Quantitative analysis showed the relative number of invaded cells counted microscopically in five different fields per filter. PSAT1transfected EC1 cells showed a significantly increased $(\mathrm{P}<0.01)$ number of invading cells compared with the vector only control, whereas PSAT1 siRNA-transfected EC9706 cells 


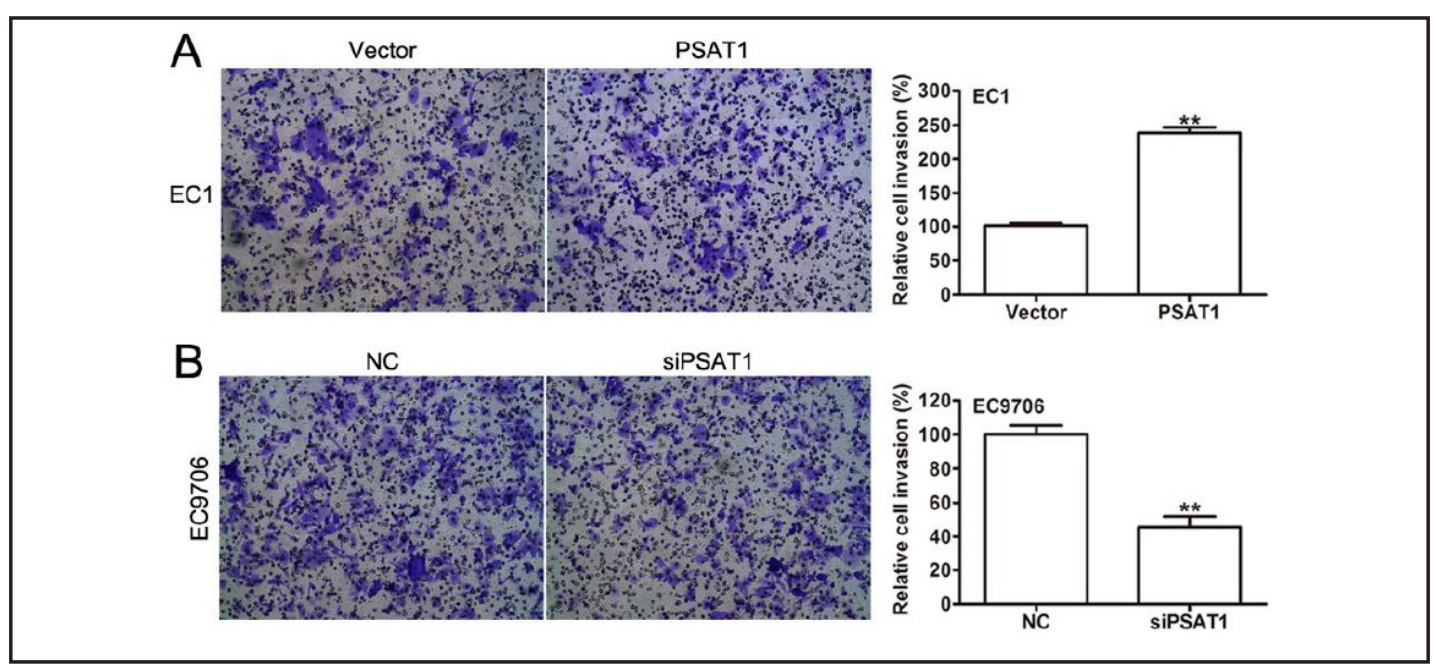

Fig. 4. The effect of PSAT1 on cell invasion in vitro. (Left) (A) Representative images of the Matrigelinvasion assay in EC1 cells transfected with PSAT1-expressing or control vector. (B) Representative images of the Matrigel invasion assay in EC9706 cells transfected with PSAT1siRNA or negative control. (Right) Quantitative analysis of the relative cell number of invaded cells counted microscopically in five different fields per filter. Results show the mean \pm standard deviation of three independent experiments.

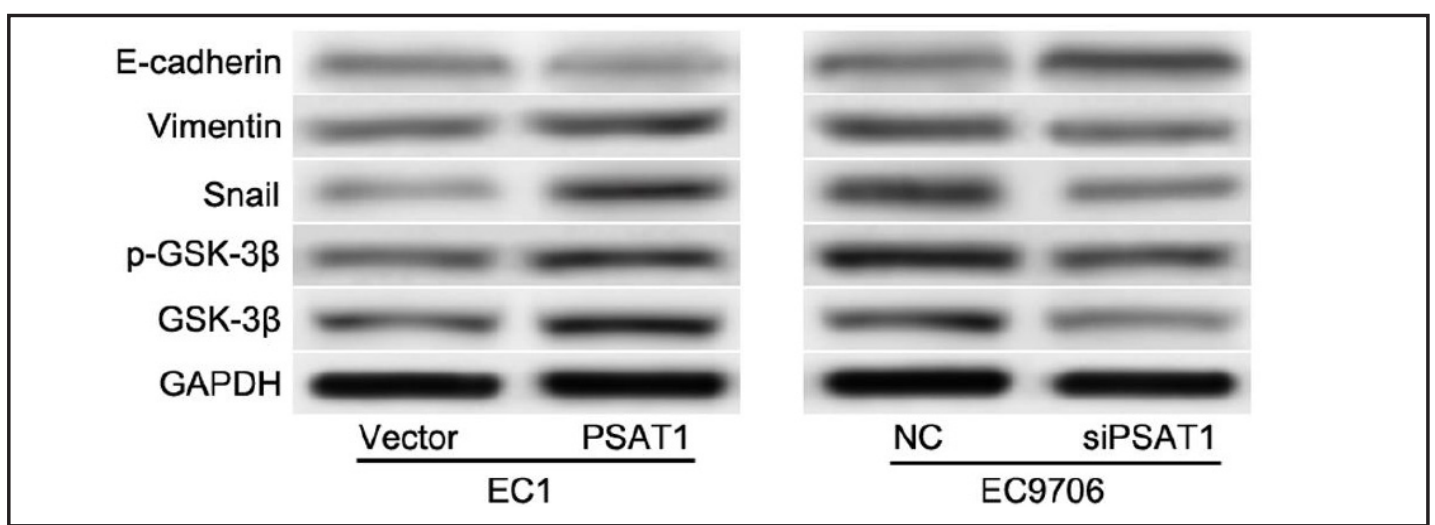

Fig. 5. The effect of PSAT1 on proteins of the GSK-3 $\beta$ pathway. Total proteins were harvested and blotted with anti-GSK-3 $\beta$, p-GSK-3 $\beta$ (Ser9), Snail, Vimentin and E-cadherin antibodies. (Left) Proteins from EC1 cells transfected with PSAT1-expressing or control vector.(Right) Proteins from EC9706 cells transfected with PSAT1siRNA or negative control.

showed a significantly decreased $(\mathrm{P}<0.01)$ number of invading cells compared with the negative control. These findings confirmed a role for PSAT1 in cell invasion in vitro.

\section{GSK-3 $\beta$ pathway activation maybe correlated with PSAT1 upregulation}

Decreased E-cadherin and elevated and elevated Vimentin expression is one of hallmark of EMT which is a key element in the cancer invasion, including EC [22]. E-cadherin mediates cell-cell adhesion, a property lost during carcinogenesis. In this study, the protein expression of E-cadherin was downregulated in PSAT1-transfected EC1 cells compared with the vector only control cells, correspondingly it was upregulated in PSAT1siRNA-transfected EC9706 cells. This finding therefore indicates PSAT1-enhanced tumorigenesis is accompanied by E-cadherin suppression and the consequent loss of cell-cell adhesion. The filament proteinVimentin shows the opposite trend, being upregulated in PSAT1-transfected EC1 cells and downregulated in PSAT1 siRNA-transfected EC9706 cells. This is consistent with Vimentin being a marker of the morphological and phenotypic changes that occur in cells during the process of carcinogenesis. 


\begin{tabular}{|c|c|c|}
\hline Cellular Physiology & Cell Physiol Biochem 2016;39:395-406 & \\
\hline and Biochemistry & $\begin{array}{l}\text { DOI: 10.1159/000445633 } \\
\text { Published online: July 04, } 2016\end{array}$ & $\begin{array}{l}\text { O } 2016 \mathrm{~S} \text {. Karger AG, Basel } \\
\text { www.karger.com/cpb }\end{array}$ \\
\hline
\end{tabular}

The PI3K/Akt/GSK3 $\beta /$ Snail signaling pathway has been implicated in the opposing processes of cellular survival and apoptosis, and aberrant signaling has been associated with carcinogenesis. GSK3 $\beta$ is a ubiquitous regulatory serine/threonine kinase with numerous cellular targets and functions that include cellular proliferation, differentiation, motility and survival [23, 24]. Expression of active GSK3 $\beta$ (not phosphorylated on serine-9) has been linked with promoting apoptosis of cancer cells. Transcription factor Snail suppresses E-cadherin effecting cell differentiation, and migratory and invasive properties, inducing cell movement and survival. It is already reported that miR-140 targeting Slug (Snail2) to regulate the invasion in EC [1]. GSK3 $\beta$ binds to and phosphorylates Snail, thereby regulating its function, and together these proteins act as a molecular switch for many signaling pathways [25]. To analyze the effect of

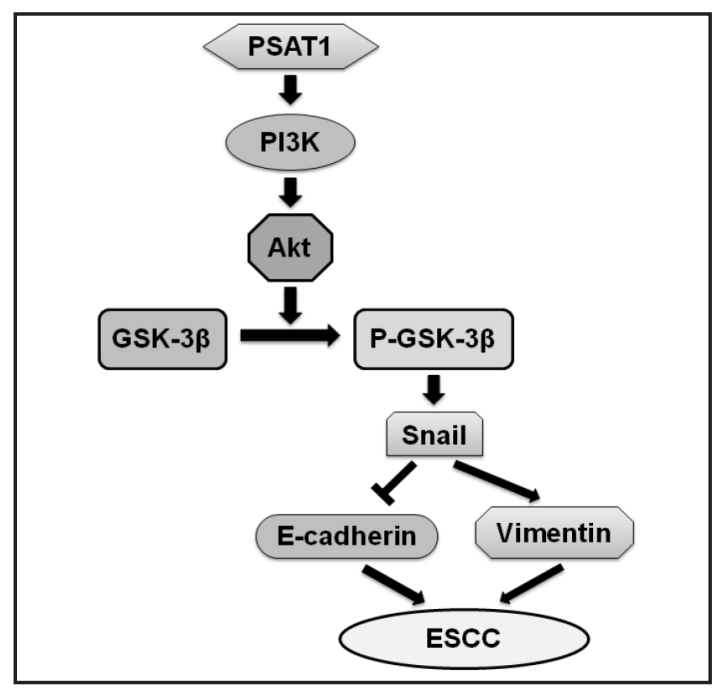

Fig. 6. Role of PSAT1 in the regulation of the PI3K/ Akt/GSK3 $3 /$ Snail signalling pathway in the pathology of ESCC. Overexpression of PSAT1 in ESCC upregulated the PI3K/Akt/GSK3 $\beta /$ Snail signaling pathway, promoting tumorigenesis.

PSAT1 on the expression of key proteins in the GSK-3 $\beta$ pathway (GSK-3 $\beta$, p-GSK-3 $\beta$ (Ser9), Snail, Vimentin and E-cadherin), western blot analysis was performed on the total protein from PSAT1-transfected EC1 cells and the corresponding vector only control cells (Fig. 5, left), and PSAT1siRNA-transfected EC9706 cells and the corresponding negative control cells (Fig. 5, right). The results of western blot analysis shown that PSAT1 appeared to upregulate the expression and/or activity of GSK3 $\beta /$ Snail. Snail was upregulated in PSAT1-transfected EC1 cellscompared with the vector only control cells, correspondingly it was downregulated in PSAT1 siRNA-transfected EC9706 cells. GSK3 $\beta$ expression showed a similar trend, being upregulated in PSAT1 overexpressing cells and downregulated in PSAT1 silenced cells. The expression of inactive phosphorylated-GSK3 $\beta$ also showed a similar trend but differential expression patterns were less pronounced. Upregulation of the PI3K/Akt/GSK3 $\beta /$ Snail signaling pathway in the presence of high levels of PSAT1 indicates the potential mechanism of action of this serine biosynthetic enzyme in cell proliferation and tumorigenesis, as shown in Fig. 6.

Taken together, our findings present further evidence of the role of serine biosynthetic enzymes in the pathology of ESCC. PSAT1 promotes cancer cell proliferation and invasion and is a prognostic predicator of poor clinical outcomes.

\section{Conclusion}

In recent years, there has been renewed focus on metabolites as anticancer therapeutic targets [26-28]. In our present study, we found that PSAT1 was increased in ESCC tissues and overexpression of PSAT1 promoted ESCC cell growth in vitro and in vivo, which indicated the deregulation of PSAT1 has a role in the pathogenesis of ESCC and that targeting these signals may have potential therapeutic value in ESCC. In addition, the GSK3 $\beta /$ Snail axis was involved in PSAT1-induced promotion of EMT and invasion, which indicated the importance of conducting further studyon the associated abnormal targeting signals of PSAT1and that targeting these signals may have potential therapeutic value in ESCC. 


\section{Acknowledgments}

This work was supported by grants from Shanghai key medical specialty construction (NO. ZK2012A04).

\section{Disclosure Statement}

The authors declare no competing interests.

\section{References}

1 Li W, Jiang G, Zhou J, Wang H, Gong Z, Zhang Z, Min K, Zhu H, Tan Y: Down-regulation of mir-140 induces emt and promotes invasion by targeting slug in esophageal cancer. Cell Physiol Biochem 2014;34:14661476.

2 Liu P, Gao Y, Huan J, Ge X, Tang Y, Shen W, Tian Y, Shen W, Zou S, Zhou J, Zhang S: Upregulation of pax2 promotes the metastasis of esophageal cancer through interleukin-5. Cell Physiol Biochem 2015;35:740754.

3 Mao WM, Zheng WH, Ling ZQ: Epidemiologic risk factors for esophageal cancer development. Asian Pac J Cancer Prev 2011;12:2461-2466.

$4 \quad$ Zhang Y: Epidemiology of esophageal cancer. World J Gastroenterol 2013;19:5598-5606.

5 Khuroo MS, Zargar SA, Mahajan R, Banday MA: High incidence of oesophageal and gastric cancer in kashmir in a population with special personal and dietary habits. Gut 1992;33:11-15.

6 Rasool S, B AG, Syed Sameer A, Masood A: Esophageal cancer: Associated factors with special reference to the kashmir valley. Tumori 2012;98:191-203.

7 Lepage C, Drouillard A, Jouve JL, Faivre J: Epidemiology and risk factors for oesophageal adenocarcinoma. Dig Liver Dis 2013;45:625-629.

8 Zhu Y, Xia Y, Niu H, Chen Y: Mir-16 induced the suppression of cell apoptosis while promote proliferation in esophageal squamous cell carcinoma. Cell Physiol Biochem 2014;33:1340-1348.

9 Guanrei Y, Songliang Q: Endoscopic surveys in high-risk and low-risk populations for esophageal cancer in china with special reference to precursors of esophageal cancer. Endoscopy 1987;19:91-95.

10 Oze I, Matsuo K, Wakai K, Nagata C, Mizoue T, Tanaka K, Tsuji I, Sasazuki S, Inoue M, Tsugane S, Research Group for the D, Evaluation of Cancer Prevention Strategies in J: Alcohol drinking and esophageal cancer risk: An evaluation based on a systematic review of epidemiologic evidence among the japanese population. Jpn J Clin Oncol 2011;41:677-692.

11 Duggan C, Onstad L, Hardikar S, Blount PL, Reid BJ, Vaughan TL: Association between markers of obesity and progression from barrett's esophagus to esophageal adenocarcinoma. Clin Gastroenterol Hepatol 2013;11:934-943.

12 Nieman KM, Romero IL, Van Houten B, Lengyel E: Adipose tissue and adipocytes support tumorigenesis and metastasis. Biochim Biophys Acta 2013;1831:1533-1541.

13 DeBerardinis RJ: Serine metabolism: Some tumors take the road less traveled. Cell Metab 2011;14:285286.

14 Antonov A, Agostini M, Morello M, Minieri M, Melino G, Amelio I: Bioinformatics analysis of the serine and glycine pathway in cancer cells. Oncotarget 2014;5:11004-11013.

15 Baek JY, Jun DY, Taub D, Kim YH: Characterization of human phosphoserine aminotransferase involved in the phosphorylated pathway of l-serine biosynthesis. Biochem J 2003;373:191-200.

16 Vie N, Copois V, Bascoul-Mollevi C, Denis V, Bec N, Robert B, Fraslon C, Conseiller E, Molina F, Larroque C, Martineau P, Del Rio M, Gongora C: Overexpression of phosphoserine aminotransferase psat1 stimulates cell growth and increases chemoresistance of colon cancer cells. Mol Cancer 2008;7:14.

17 Ojala P, Sundstrom J, Gronroos JM, Virtanen E, Talvinen K, Nevalainen TJ: Mrna differential display of gene expression in colonic carcinoma. Electrophoresis 2002;23:1667-1676. 


\section{Cellular Physiology Cell Physiol Biochem 2016;39:395-406 \begin{tabular}{l|l|l} 
DOI: 10.1159/000445633 & $\begin{array}{l}\text { O 2016 S. Karger AG, Basel } \\
\text { www.karger.com/cpb }\end{array}$
\end{tabular} \\ Liu et al.: Role of PSAT1 in ESCC}

18 Friederichs J, Rosenberg R, Mages J, Janssen KP, Maeckl C, Nekarda H, Holzmann B, Siewert JR: Gene expression profiles of different clinical stages of colorectal carcinoma: Toward a molecular genetic understanding of tumor progression. Int J Colorectal Dis 2005;20:391-402.

19 Martens JW, Nimmrich I, Koenig T, Look MP, Harbeck N, Model F, Kluth A, Bolt-de Vries J, Sieuwerts AM, Portengen H, Meijer-Van Gelder ME, Piepenbrock C, Olek A, Hofler H, Kiechle M, Klijn JG, Schmitt M, Maier S, Foekens JA: Association of DNA methylation of phosphoserine aminotransferase with response to endocrine therapy in patients with recurrent breast cancer. Cancer Res 2005;65:4101-4117.

20 Yang Y, Wu J, Cai J, He Z, Yuan J, Zhu X, Li Y, Li M, Guan H: Psat1 regulates cyclin d1 degradation and sustains proliferation of non-small cell lung cancer cells. Int J Cancer 2015;136:E39-50.

21 Yan S, Jiang H, Fang S, Yin F, Wang Z, Jia Y, Sun X, Wu S, Jiang T, Mao A: Microrna-340 inhibits esophageal cancer cell growth and invasion by targeting phosphoserine aminotransferase 1. Cell Physiol Biochem 2015;37:375-386.

22 Niu H, Gong L, Tian X, Fang L, Wang C, Zhu Y: Low expression of mir-491 promotes esophageal cancer cell invasion by targeting tpx2. Cell Physiol Biochem 2015;36:2263-2273.

23 Lan A, Qi Y, Du J: Akt2 mediates tgf-beta1-induced epithelial to mesenchymal transition by deactivating gsk3beta/snail signaling pathway in renal tubular epithelial cells. Cell Physiol Biochem 2014;34:368-382.

24 Luo J: Glycogen synthase kinase 3beta (gsk3beta) in tumorigenesis and cancer chemotherapy. Cancer Lett 2009;273:194-200.

25 Barrallo-Gimeno A, Nieto MA: The snail genes as inducers of cell movement and survival: Implications in development and cancer. Development 2005;132:3151-3161.

26 Harris AL: Metabolic compartments in tumor tissue: Implications for therapy. Cell Cycle 2012;11:13-14.

27 Zhao Y, Butler EB, Tan M: Targeting cellular metabolism to improve cancer therapeutics. Cell Death Dis 2013;4:e532.

28 Ross SJ, Critchlow SE: Emerging approaches to target tumor metabolism. Curr Opin Pharmacol 2014; $17: 22-29$. 